\title{
NEXUS OF AGRICULTURE, GDP, POPULATION AND CLIMATE CHANGE: CASE OF SOME EURASIAN COUNTRIES AND TURKEY
}

\author{
DOĞAN, H. G. \\ Department of Agricultural Economics, Agricultural Faculty, Kirsehir Ahi Evran University \\ 40100 Kirsehir Province, Turkey \\ (e-mail: hg.dogan@ahievran.edu.tr; phone: +90-386-280-4869) \\ (Received $7^{\text {th }}$ Jul 2018; accepted $20^{\text {th }}$ Sep 2018)
}

\begin{abstract}
Climate has an important role in the life processes of living creatures economically, socially and biologically. It affects several sectors and is affected by several sectors. Climate events are known to have changed since the second millennium and today it stands out as a problem that humanity has to face. Climate change has to be evaluated together with the global warming phenomenon. The most important factor causing global warming is the $\mathrm{CO}_{2}$ concentration. This study examines the effects of variables including the share of the agricultural fields within total area, agricultural added value, GDP and population on the $\mathrm{CO}_{2}$ release within the scale of the Eurasian Region and Turkey. The study covers the period between 1993 and 2016 years. Econometric models like ADF unit square test, ARDL and VECM were used. According to the obtained results, the effect of population was determined to be greater than that of the other variables in both regions. All of the variables under study had an increasing effect on $\mathrm{CO}_{2}$ release in the long term in the Eurasian Region, while the share of the agricultural areas within total area and the GDP variables had an effect to reduce $\mathrm{CO}_{2}$ release. This different situation is directly related to the size of the agricultural production in the Eurasian Region and Turkey and to the awareness level of the people. As a result, awareness of the individuals as well as of the state rulers on environmental destruction or environmental cost in particular in all works is considered to be important. On the other hand, it is necessary to plan agricultural production system within an environmental dimension and this needs to become a state policy. However, when creating these policies, one should avoid practices causing any difficulty in meeting the food demand of the population or causing excessive increases in food prices, such as the results when agriculture was affected by the climate events. Otherwise, there may be undesired consequences like food deficiency and corresponding deterioration of the macroeconomic balances of countries.
\end{abstract}

Keywords: $\mathrm{CO}_{2}, \mathrm{ARDL}, \mathrm{VECM}$, Eurasia, Turkey

\section{Introduction}

Climate is an important environmental element affecting life on Earth (Carson, 1999). However, it has significantly changed in recent years. The change process started with the industrial revolution continued with the burning of fossil fuels and with human activities. It leads to the phenomenon of global warming. Climate change affects every stage of our lives, especially physical and natural environment (Özdemir et al., 2017). Global warming and climate change have important effects on the economies of developed and developing countries. It is stated that the concerned economic effects may reach to enormous levels if the necessary measures to reduce release and measures for compliance are not taken. The global warming and climate change have directly or indirectly affected all regions of the world in recent years. The sensible effects are more visible in the last few decades. These effects are expected to increase further in years to come. In other words, global warming and climate change is a global phenomenon at present (Gafari et al., 2014). The primary accountable element of the said phenomenon is human activity. Human activities cause global warming and increase the greenhouse gas release that leads to great changes in global climate. Several extreme events may occur due to climate change. These include irregular precipitation periods, irregular wind directions, increased level of drought, 
desertification, and changes in underground and surface water levels (Angel, 2008). Technological development and welfare increase have been an important factor in greenhouse gas release. The basic sources for the greenhouse concentration can be defined with the use of fossil fuels in sectors like electricity generation, agricultural production and transportation. It is stated that the result may have huge negative regional, country based and global effects (Janjua et al., 2014). These effects occur with the accumulation of the greenhouse gases. Scientists agree on the fact that the basic cause of this problem is due to greenhouse gases like $\mathrm{CO}_{2}$.

According to the present calculation, it is estimated that only a $1{ }^{\circ} \mathrm{C}$ increase in global warming will lead to an annual economic cost of 2 trillion dollars in 2050. According to a study conducted in EU, the cumulative global economic cost of global warming may reach to Euro 74 trillion (Bayraç and Doğan, 2016). It has been a significant increase in the amount of greenhouse gas in the atmosphere since the industrial revolution. Since 1750, the $\mathrm{CO}_{2}$ level in the atmosphere increased nearly by $30 \%$ and reached from 280 ppm to 380 ppm. Today, $\mathrm{CO}_{2}$ concentration increases around by $1.5 \mathrm{ppm}$ every year. Therefore, it is necessary to keep the atmospheric greenhouse concentrations under control through various methods (Bayraç and Doğan, 2016). There are main sectors causing greenhouse gas release. Figure 1 includes sectoral greenhouse gas releases at a global scale. As shown in Figure 1, the greenhouse gas releases are caused by industry $(21 \%)$, transportation $(14 \%)$, buildings (6\%), agriculture and forestry and other field uses (24\%), power and heat generation (25\%), and other energy generation (10\%) (IPCC, 2014a).

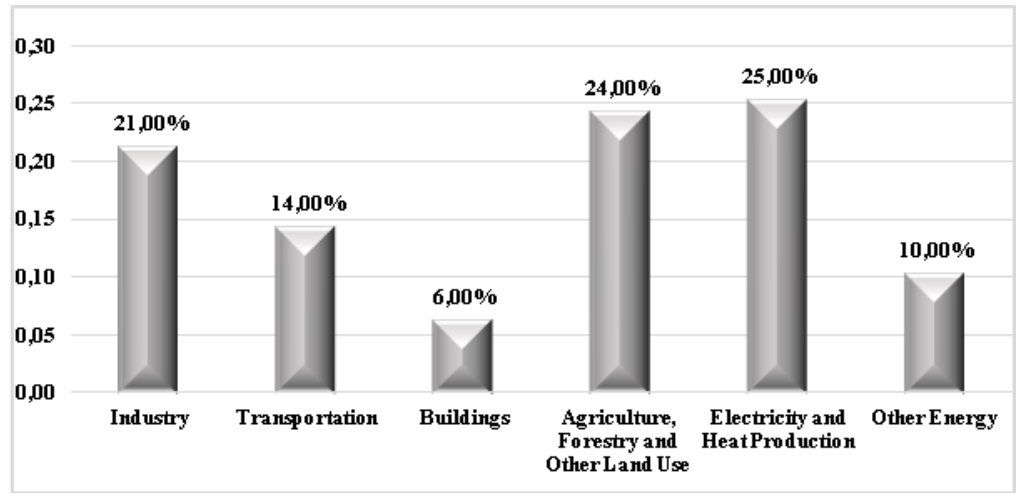

Figure 1. Sectoral greenhouse release (IPCC, 2014a)

Sectoral greenhouse releases stated by IPCC are in one aspect directly related to the energy consumption. It is estimated that the total global energy supply will double between 2004 and 2020 (Kaygusuz, 2009). On sectoral basis, energy sources may vary and substitute each other. It is stated that the $24 \%$ coal share in 2004 will increase to $36 \%$ in 2020 and substitute oil in certain extent. After such a substitution, the $\mathrm{CO}_{2}$ release is expected to increase three times between 2004 and 2020 (Kaygusuz, 2009).

Climate change affects various economic sectors including agriculture, forestry, water, industry, tourism, energy and even finance and insurance markets with agriculture being the most sensitive to these changes (Hosseini et al., 2013). Agricultural sector is affected more by the climate events than the others. It is a high risk sector as it is inherently based on natural conditions. Agricultural sector has dynamics causing climate change and it has a decisive role for production and sustainability in both short term and long term (Gafari et al., 2014). It is proportionally 
the second biggest sector contributing to the greenhouse release (IPCC, 2014b). The greenhouse gas emission in the agriculture sector contributing by $24 \%$ is caused by soil processing during production process and animal activities, heat and electrical energy generation, agricultural equipment, inorganic manure, agricultural chemicals and fossil fuels used in tractors and other transportation vehicles. ABD emission statistics report that the agricultural sector is directly responsible for greenhouse release. Soil management is defined to be the most important dynamic in the sector (Holly, 2015). Reynolds and Wenzlau (2012) reported that the agriculture sector has a 14 to $30 \%$ contribution to the total greenhouse emission due to irrigation and nitrogen rich fertilizers. In another aspect, agriculture is a sector that is affected by climate change. That is, it both causes and is significantly affected by climate change and global warming. The agricultural sector is highly dependent on climate events. This dependency directly affects food supply, agricultural food products and sectoral economic performance (Holly, 2015; Sakurai et al., 2014; Kang et al., 2009; Magadza, 2000).

As stated by World Bank (2016a, b), global agricultural sector produces $\mathrm{CO}_{2}, \mathrm{CH}_{4}$ and $\mathrm{N}_{2} \mathrm{O}$. However, the $\mathrm{CH}_{4}$ and $\mathrm{N}_{2} \mathrm{O}$ concentration are lower than the $\mathrm{CO}_{2}$ concentration. $\mathrm{CO}_{2}$ concentration had a 40\% increase from 1750 to 2014 (IPCC, 2014b). United Nations Food and Agriculture Organization (FAO) states that the agricultural sector has a potential to reach an 80 to $88 \%$ reduction in the $\mathrm{CO}_{2}$ emissions it causes at the moment (Reynolds and Wenzlau, 2012). Based on this result, it can be considered that environmental damage is not a must for economic and agricultural growth. Several attempts have been made to find a scientific answer to this question. It is emphasized that growth increase depends on various factors including energy consumption, food demand and land usage and leads to increases in $\mathrm{CO}_{2}$ emissions. However, the agricultural sector contributes to the greenhouse release by producing $\mathrm{CO}_{2}$ and causes global warming while it helps to reduce the $\mathrm{CO}_{2}$ level by producing more $\mathrm{O}_{2}$ through plantation (Khasman et al., 2016). It is clear that proper approaches are necessary for the organization of this two-way action-reaction process.

Humanity faces increasing threats with respect to global warming and climate change every day on one hand, and food demand and economic growth quests on the other. When we take a liveable world as a priority, energy consumption, considered among the main contaminants, becomes a focal point in this matter. Therefore, there has been a demand for empirical studies on energy consumption, economic growth and their environmental costs. When we look at the results obtained from the said studies, we notice the presence of strong relation between these variables that are studied. Since the last quarter of the second millennium, that is within period of oil wars and thereafter, scientific studies happened to have different dimensions with the Kyoto Protocol. These research studies indicate the fact that the studies on energy economy and environment economy cover a very important field. However, the results highlight the necessity to increase the energy consumption to ensure the targeted growth rates despite the potential environmental cost (Tiwari, 2011). The present study intends to bring a perspective from the agricultural dimension to the greenhouse effect, which is one of the main causes of global warming and climate change. Eurasian countries and Turkey were selected as the study region. It is intended to compare two regions with different population growth and economic structures. Despite these differences, it is aimed to study the comparative conditions of the two regions that are within the same geopolitical frame. The variables that are studied include two important variables. 
Because, agriculture has an effect to reduce both global warming and climate change while it has also an effect to increase global warming and climate change by greenhouse gas release (Bayraç and Doğan, 2016). In addition, the variables including population and national income per capita were examined in the study as the other important determinants. As it was already mentioned, the main reason of the global warming and climate change process has a human root.

Figures 2 and 3 include the development trend of the Eurasian countries and Turkey between the years 1993 and 2016 years with respect to the variables under the study.

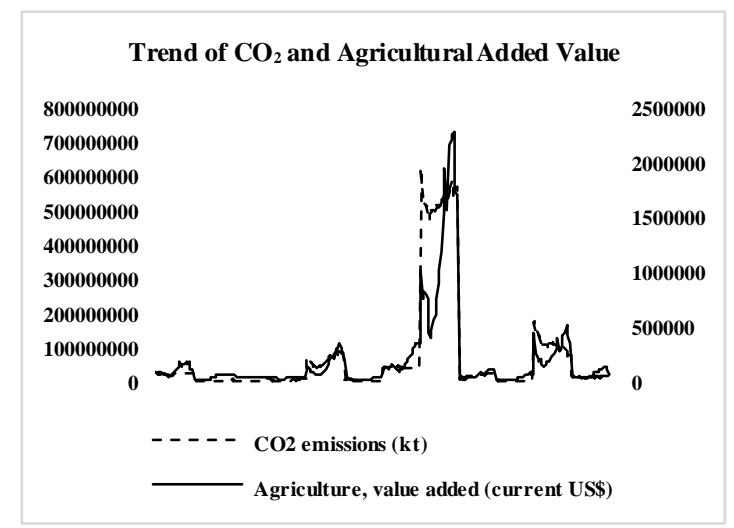

$\mathbf{a}$

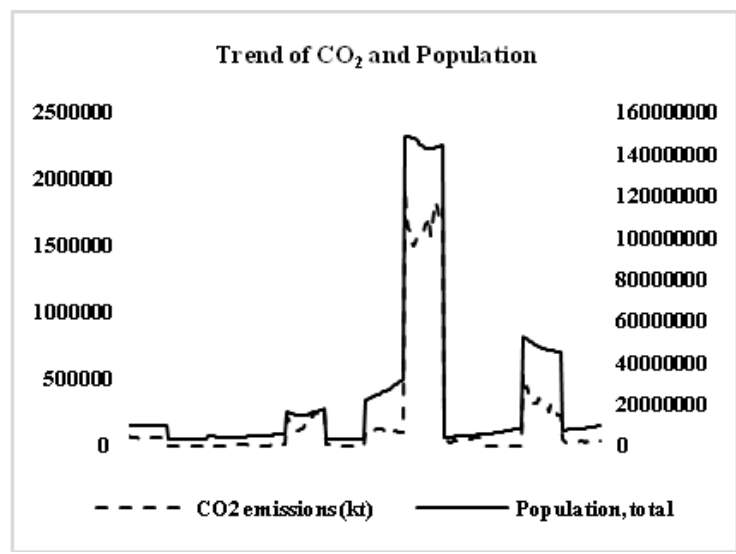

a

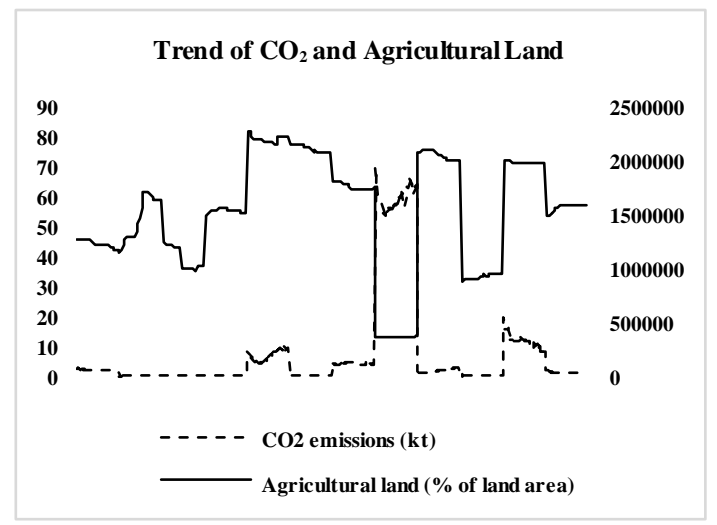

$\mathbf{b}$

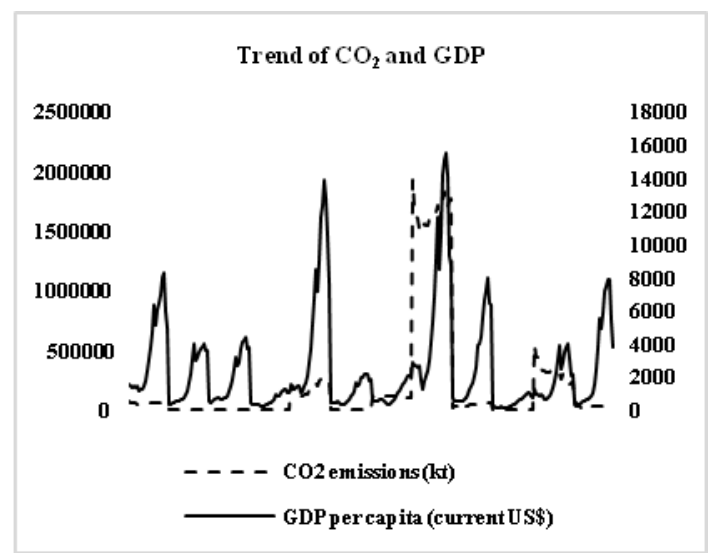

b

Figure 2. The interaction among agricultural added value (a), agricultural land (b), population (c) and GDP (d) and $\mathrm{CO}_{2}$ in Eurasian countries (Wolrdbank, 2017). Note: X-axis represents the Eurasian countries (12 countries) between 1993 and 2016 years

When we examine the trend of variables in the Eurasian countries between 1993 and 2016 years, the trends of $\mathrm{CO}_{2}$ and other variables are similar with the direction of the coefficients obtained from the econometric results. It is possible to see in Figure 2 that agricultural added value, population and GDP have movements in the same direction. This simultaneous trend differs only in the Russian Federation within the panel addressed with respect to agricultural field. The reason is that agricultural production is very low in the Russian Federation (average share of the agricultural added value within GDP between 1993 and 2016 years is $4.88 \%$; the lowest among 12 countries within the Eurasian region (World Bank, 2017). It can be said that the other factors increasing the 
$\mathrm{CO}_{2}$ level in the Russian Federation are more effective. However, it cannot be said that this is valid for all of the panel.

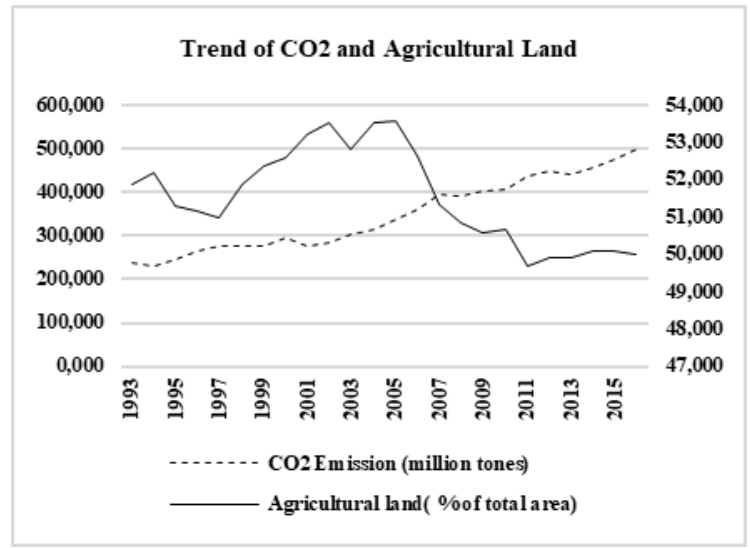

$\mathbf{a}$

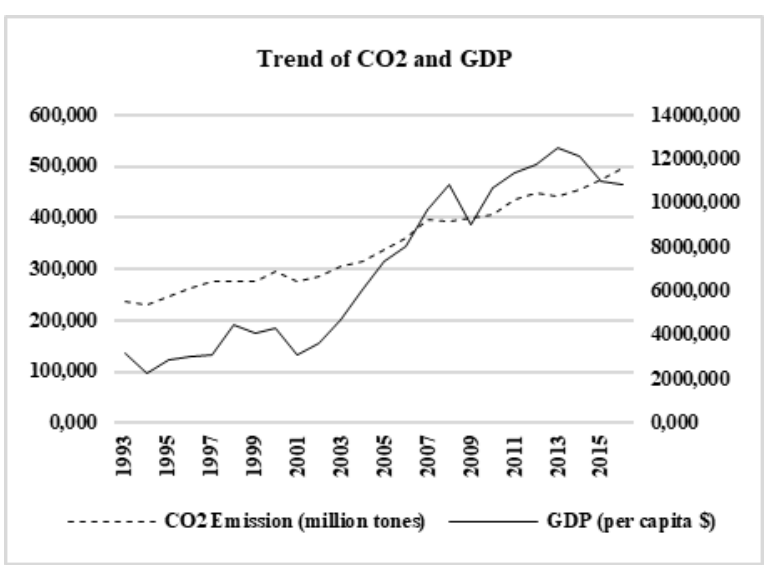

c

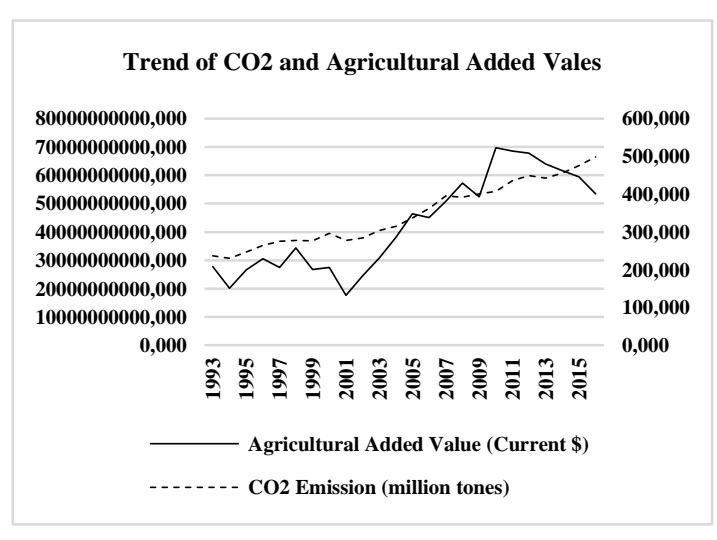

b

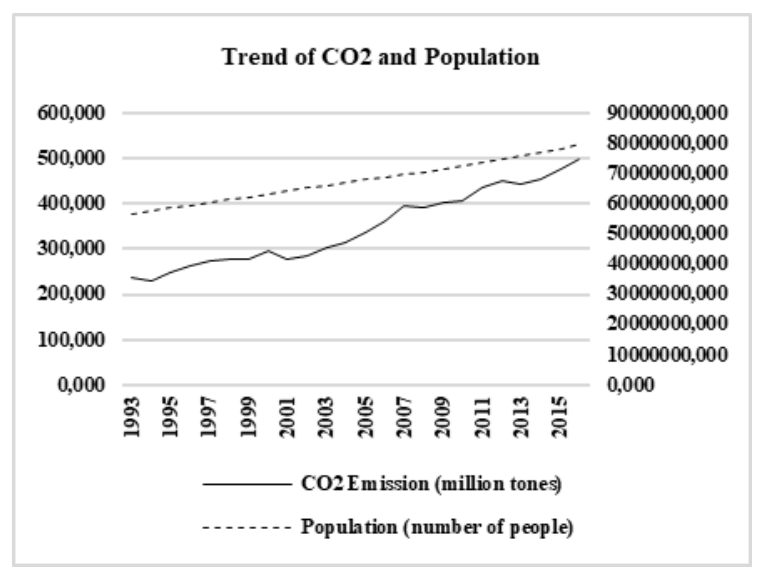

d

Figure 3. The interaction among agricultural land (a), Agricultural added value (b), GDP (c), population (d) and $\mathrm{CO}_{2}$ in Turkey (World Bank, 2017). Note: X-axis represents between 1993 and 2016 years

Figure 3 indicates the interaction between $\mathrm{CO}_{2}$ release in Turkey and agricultural area, agricultural added value, population and GDP. Accordingly, the long time trend of the variables develops in the same trend as $\mathrm{CO}_{2}$. However, the interaction of agricultural fields and $\mathrm{CO}_{2}$ should be kept different from this framework because the increase in $\mathrm{CO}_{2}$ release continues even if the share of the agricultural fields has a decreasing trend after 2005. This can be linked to the fact that the agricultural fields in Turkey face urbanization and housing despite they are under the status of agricultural production.

\section{Materials and methods}

In the study, factors affecting $\mathrm{CO}_{2}$ release in Eurasian countries and Turkey were investigated. The study involved the years between 1993 and 2016 years. These factors are the share of agricultural areas in total area, agricultural added value, GDP and population. Eurasia is defined from United Kingdom to Japan in the literature. It includes 103 countries (Anonymous, 2018). This concept was firstly used by Alexander 
von Humbolt in 1849 (İşyar, 2013). Although there is no consensus on the scope of this concept, there are many approaches that cover various countries. Countries emerging after the dissolution of the Soviet Union are also located within this region. It can be said that they are intensely related to each other in terms of culture, politics and economics. Therefore, in this study, 12 countries with similar characteristics were named as the Eurasian region. These are Belarus, Armenia, Georgia, Kazakhstan, Kyrgyzstan, Moldova, Uzbekistan, Russia, Tajikistan, Turkmenistan, Ukraine and Azerbaijan. Panel data analysis was used for the modelling of 12 countries while time series analysis was used in the econometric modelling for Turkey. Table 1 includes the symbols and data sources of the variables.

Table 1. Symbols and data sources of the variables used in the study

\begin{tabular}{c|c|c|c}
\hline Name of the variable & Symbol & Unit & Data source \\
\hline $\mathrm{CO}_{2}$ & $\mathrm{Y}$ & $\begin{array}{c}\text { For Eurasia; kgtonnes/for Turkey; million } \\
\text { tones }\end{array}$ & $\begin{array}{c}\text { World Bank, } \\
\text { Turkstat }\end{array}$ \\
\hline $\begin{array}{c}\text { Share of agricultural fields } \\
\text { within total area }\end{array}$ & $\chi$ & \% of land area & World Bank \\
\hline Agricultural added value & $\sigma$ & current US\$ & World Bank \\
\hline GDP per capita & $\lambda$ & current US\$ & World Bank \\
\hline Population & $\delta$ & Total number of people & World Bank \\
\hline
\end{tabular}

Full logarithmic form was chosen in the study for the variables used in the model. The functional relation between the $\mathrm{CO}_{2}$ level and other variables can be expressed as follows in Equation 1:

$$
\ln \mathrm{Y}=f(\ln \chi, \ln \sigma, \ln \lambda, \ln \delta)
$$

The factors causing the long term greenhouse gas effect in both the Eurasian Region and Turkey were analysed by means of the following economic models:

- Unit root test (ADF)

- Autoregressive distributed lag bound test (ARDL)

- Vector error correction model (VECM)

Unit root test is used to carry out the stability studies of the series. Stability tests are carried out to avoid the spurious regression problem. Several studies in the literature revealed the necessity to carry out the unit root tests (Maddala and Shaowen, 1999; Kao and Chiang, 2000; Hadri, 2000; Choi, 2001; Levin et al., 2002; Im, 2003). There are several types of the unit root test. However, basically the unit root tests are based on the ADF principle. This study also used the ADF unit root test. The notation of the ADF test statistics can be stated as follows in Equation 2:

$$
\Delta X_{t}=\beta_{0}+\beta_{1} t+\beta_{i} X_{t-1}+\sum_{j=1}^{n} Y_{i} \Delta X_{t-j}+e_{t}
$$

In Equation 2, $\beta 0$ refers to fixed term; $\mathrm{t}$ refers to deterministic trend; $\mathrm{n}$ refers to lag length and $e_{t}$ refers to stochastic term. The results of the ADF test statistics are 
compared by means of the MacKinnon critical value. Stability of the series is decided by accepting/rejecting according to the importance levels of $1 \%, 5 \%$ and $10 \%$ (MacKinnon, 1996).

\section{Autoregressive distributed lag (ARDL) and vector error correction model (VECM)}

The frequently used models in the literature are the Engle-Granger model (1987) based on the error term in the co-integration tests, Johansen model (1988) and Johansen \& Jesilius model (1990) based on system approach (Altıntaş, 2013). However, stability approach at the $\mathrm{I}(0)$ level of all variables provides validity of these methods (Pesaran and Shin, 1995; Pesaran et al., 2001). The advantage of the ARDL approach is that it can carry out the co-integration test without considering the integration levels of the variables. There are basically 3 important points to pay attention to in the method. Ilimit test procedure is easy and it is possible to carry out co-integration relation test after determining the lag length contrary to the multivariable co-integration methods like Johansen and Juselius (1990). II-limit test procedure does not require the preliminary tests of the variables included in the unit root test model, which is different from the cointegration techniques of Johansen and Juselius (1990). The limit test can be applied regardless of the fact that the models in the series are at the I(2) level, I(0) level and I(1) level or mutually co-integrated at the same level. III-limit test is very effective for small or limited sample clusters.

Equations 3, 4, 5, 6 and 7 include the limit test models of the 4 independent variables that were adapted to the study and the notations based on the estimation of the unlimited error correction model by the OLS method.

$$
\begin{aligned}
\Delta \ln \mathrm{Y} & =\beta_{0}+\sum_{i=1}^{m} \beta_{1 i} \Delta \ln \mathrm{Y}_{t-i}+\sum_{i=0}^{m} \beta_{2 i} \Delta \ln \chi_{t-i}+\sum_{i=0}^{m} \beta_{3 i} \Delta \ln \sigma_{t-i}+\sum_{i=0}^{m} \beta_{4 i} \Delta \ln \lambda_{t-i}+\sum_{i=0}^{m} \beta_{5 i} \Delta \ln \delta_{t-i} \\
& +\mathrm{a} 1 \ln \mathrm{Y}_{t-1} \mathrm{a} 2 \ln \chi_{t-1}+\mathrm{a} 3 \ln \sigma_{t-1}+\mathrm{a} 4 \ln \lambda_{t-1}+\mathrm{a} 5 \ln \delta_{t-1}+u_{t} \\
\Delta \ln \chi & =V_{0}+\sum_{i=1}^{m} \beta_{1 i} \Delta \ln \chi_{t-i}+\sum_{i=0}^{m} \beta_{2 i} \Delta \ln \mathrm{Y}_{t-i}+\sum_{i=0}^{m} \beta_{3 i} \Delta \ln \sigma_{t-i}+\sum_{i=0}^{m} \beta_{4 i} \Delta \ln \lambda_{t-i}+\sum_{i=0}^{m} \beta_{5 i} \Delta \ln \delta_{t-i} \\
& +\mathrm{a} 1 \ln \mathrm{Y}_{t-1} \mathrm{a} 2 \ln \chi_{t-1}+\mathrm{a} 3 \ln \sigma_{t-1}+\mathrm{a} 4 \ln \lambda_{t-1}+\mathrm{a} 5 \ln \delta_{t-1}+u_{t} \\
\Delta \ln \sigma & =K_{0}+\sum_{i=1}^{m} \beta_{1 i} \Delta \ln \sigma_{t-i}+\sum_{i=0}^{m} \beta_{2 i} \Delta \ln \mathrm{Y}_{t-i}+\sum_{i=0}^{m} \beta_{3 i} \Delta \ln \chi_{t-i}+\sum_{i=0}^{m} \beta_{4 i} \Delta \ln \lambda_{t-i}+\sum_{i=0}^{m} \beta_{5 i} \Delta \ln \delta_{t-i} \\
& +\mathrm{a} 1 \ln \mathrm{Y}_{t-1} \mathrm{a} 2 \ln \chi_{t-1}+\mathrm{a} 3 \ln \sigma_{t-1}+\mathrm{a} 4 \ln \lambda_{t-1}+\mathrm{a} 5 \ln \delta_{t-1}+u_{t} \\
\Delta \ln \lambda= & \mathrm{Z}_{0}+\sum_{i=1}^{m} \beta_{1 i} \Delta \ln \lambda_{t-i}+\sum_{i=0}^{m} \beta_{2 i} \Delta \ln \chi_{t-i}+\sum_{i=0}^{m} \beta_{3 i} \Delta \ln \sigma_{t-i}+\sum_{i=0}^{m} \beta_{4 i} \Delta \ln \mathrm{Y}_{t-i}+\sum_{i=0}^{m} \beta_{5 i} \Delta \ln \delta_{t-i} \\
+ & \mathrm{a} 1 \ln \mathrm{Y}_{t-1} \mathrm{a} 2 \ln \chi_{t-1}+\mathrm{a} 3 \ln \sigma_{t-1}+\mathrm{a} 4 \ln \lambda_{t-1}+\mathrm{a} 5 \ln \delta_{t-1}+u_{t} \\
\Delta \ln \delta= & \mathrm{Q}{ }_{0}+\sum_{i=1}^{m} \beta_{1 i} \Delta \ln \delta_{t-i}+\sum_{i=0}^{m} \beta_{2 i} \Delta \ln \chi_{t-i}+\sum_{i=0}^{m} \beta_{3 i} \Delta \ln \sigma_{t-i}+\sum_{i=0}^{m} \beta_{4 i} \Delta \ln \lambda_{t-i}+\sum_{i=0}^{m} \beta_{5 i} \Delta \ln \mathrm{Y}_{t-i} \\
& +\mathrm{a} 1 \ln \mathrm{Y}_{t-1} \mathrm{a} 2 \ln \chi_{t-1}+\mathrm{a} 3 \ln \sigma_{t-1}+\mathrm{a} 4 \ln \lambda_{t-1}+\mathrm{a} 5 \ln \delta_{t-1}+u_{t}
\end{aligned}
$$

In Equations 3, 4, 5, 6 and $7 \Delta$ refers to the difference processor, and $\mathrm{m}$ refers to lag length. Information criteria like AIC, SC, FPE and HQ are used to determine the lag 
length. Here, the lag length providing the smallest critical value is determined to be the lag length of the model. The process continues by passing to the next lag value like the first smallest value, the second smallest value ... etc until reaching to the model without autocorrelation. The significance of the one-lag level values of the variables is tested to determine the presence of long term co-integration between the variables by using the Ftest. $\mathrm{H}_{0}$ hypothesis indicates that there is no co-integration between the variables in the Equations 3-7 and it is formed as follows: $\mathrm{H}_{0}$ : $\mathrm{a} 1=\mathrm{a} 2=\mathrm{a} 3=\mathrm{a} 4=\mathrm{a} 5$. The alternative hypothesis $\mathrm{H}_{1}$ which indicates the presence of co-integration is formed as follows: $\mathrm{H}_{1}$ : al $\neq \mathrm{a} 2 \neq \mathrm{a} 3 \neq \mathrm{a} 4 \neq \mathrm{a} 5$. In the study, co-integration between series was searched and then the long term ARDL model on the greenhouse release and error correction model (VECM) was estimated.

The VECM model allows the estimation of the short and long term flexibilities as well as the deviation coefficient from the balance taking place between the variables (Enders, 2008). In addition, the VECM analysis allows the removal of the spurious regression problem that may occur between the dependent and descriptive variables. Equations 8, 9, 10, 11 and 12 include a corresponding VECM model (Granger, 1988).

$$
\begin{aligned}
\Delta \ln Y & =\beta_{0}+\sum_{i=1}^{m} \beta_{1 i} \Delta \ln Y_{t-i}+\sum_{i=0}^{m} \beta_{2 i} \Delta \ln \chi_{t-i}+\sum_{i=0}^{m} \beta_{3 i} \Delta \ln \sigma_{t-i}+\sum_{i=0}^{m} \beta_{4 i} \Delta \ln \lambda_{t-i}+\sum_{i=0}^{m} \beta_{5 i} \Delta \ln \delta_{t-i} \\
& +\Psi E C M_{t-1}+\varepsilon_{t} \\
\Delta \ln \chi & =V_{0}+\sum_{i=1}^{m} \beta_{1 i} \Delta \ln \chi_{t-i}+\sum_{i=1}^{m} \beta_{2 i} \Delta \ln Y_{t-i}+\sum_{i=1}^{m} \beta_{3 i} \Delta \ln \sigma_{t-i}+\sum_{i=1}^{m} \beta_{4 i} \Delta \ln \lambda_{t-i}+\sum_{i=1}^{m} \beta_{5 i} \Delta \ln \delta_{t-i} \\
& +\Psi E C M_{t-1}+u_{t} \\
\Delta \ln \sigma & =K_{0}+\sum_{i=1}^{m} \beta_{1 i} \Delta \ln \sigma_{t-i}+\sum_{i=1}^{m} \beta_{2 i} \Delta \ln Y_{t-i}+\sum_{i=1}^{m} \beta_{3 i} \Delta \ln \chi_{t-i}+\sum_{i=1}^{m} \beta_{4 i} \Delta \ln \lambda_{t-i}+\sum_{i=1}^{m} \beta_{5 i} \Delta \ln \delta_{t-i} \\
& +\Psi E C M_{t-1}+v_{t} \\
\Delta \ln \lambda & =\mathrm{Z}_{0}+\sum_{i=1}^{m} \beta_{1 i} \Delta \ln \lambda_{t-i}+\sum_{i=1}^{m} \beta_{2 i} \Delta \ln \chi_{t-i}+\sum_{i=1}^{m} \beta_{3 i} \Delta \ln \sigma_{t-i}+\sum_{i=1}^{m} \beta_{4 i} \Delta \ln Y_{t-i}+\sum_{i=1}^{m} \beta_{5 i} \Delta \ln \delta_{t-i} \\
& +\Psi E C M_{t-1}+z_{t} \\
\Delta \ln \delta & =\mathrm{Q}_{0}+\sum_{i=1}^{m} \beta_{1 i} \Delta \ln \delta_{t-i}+\sum_{i=1}^{m} \beta_{2 i} \Delta \ln \chi_{t-i}+\sum_{i=1}^{m} \beta_{3 i} \Delta \ln \sigma_{t-i}+\sum_{i=1}^{m} \beta_{4 i} \Delta \ln \lambda_{t-i}+\sum_{i=1}^{m} \beta_{5 i} \Delta \ln Y_{t-i} \\
& +\Psi E C M_{t-1}+k_{t}
\end{aligned}
$$

Equations 8, 9, 10, 11 and 12 are analyzed and interpretation is possible depending on the fact that the ECM coefficient is both statistically significant and negative or positive.

\section{Empirical results}

The presence of unit root in the series was searched first before evaluating the relation between $\mathrm{CO}_{2}$ and other variables in short and long term. Table 2 includes the unit root test results related to the variables that were examined. 
Table 2. Unit root test

\begin{tabular}{|c|c|c|c|c|c|c|c|c|}
\hline & \multicolumn{8}{|c|}{ ADF } \\
\hline & \multicolumn{4}{|c|}{ Eurasia } & \multicolumn{4}{|c|}{ Turkey } \\
\hline & \multicolumn{2}{|c|}{ Individual intercept } & \multicolumn{2}{|c|}{$\begin{array}{c}\text { Individual intercept } \\
\text { and trend }\end{array}$} & \multicolumn{2}{|c|}{ Intercept } & \multicolumn{2}{|c|}{ Intercept and trend } \\
\hline & Level & 1st Dif. & Level & 1st Dif. & Level & 1st Dif. & Level & 1st Dif. \\
\hline $\mathrm{Y}$ & 0.65 & $-9.20 *$ & $-3.57 *$ & $-7.22 *$ & -0.58 & $-3.60 *$ & -2.25 & $-3.50 * * *$ \\
\hline$\chi$ & -0.12 & $-3.79 *$ & 1.63 & $-2.21^{*}$ & -0.71 & $-3.75^{*}$ & -1.37 & $-3.68 * *$ \\
\hline$\sigma$ & 1.97 & $-5.84^{*}$ & -0.62 & $-2.93 *$ & -1.15 & $6.08^{*}$ & -2.32 & $-5.99 *$ \\
\hline$\lambda$ & 1.97 & $-2.92 *$ & 1.88 & $-2.78^{*}$ & -0.82 & $-5.72 *$ & -2.27 & $-5.78 *$ \\
\hline$\delta$ & 1.06 & $-2.29 *$ & $-1.55 * * *$ & $-2.17^{*}$ & 1.68 & $-3.17 * *$ & $-5.21 *$ & $-3.47 * * *$ \\
\hline
\end{tabular}

$*$, ** and *** mean significant, respectively, at $1 \%, 5 \%$ and $10 \%$. According to SIC. Y: $\mathrm{CO}_{2}, \chi$ : share of agricultural fields within total area, $\sigma$ : agricultural added value, $\lambda$ : GDP per capita, $\delta$ : population

According to the unit root test results which reveal whether the variables are affected by the past values, all of the variables are not stable at I(0) level per Individual Intercept in the Eurasian countries. However, they are stable at I(1) level.

Individual intercept and trend are stable at the $\mathrm{CO}_{2}$ and population $\mathrm{I}(0)$ level while the other variables are not stable. At I(1) level, all variables were determined to be stable. A similar case can also be stated for Turkey. According to Intercept, all variables are not stable at $\mathrm{I}(0)$ level. And they are all stable at $\mathrm{I}(1)$ level. According to Intercept and Trend, population is stable at $\mathrm{I}(0)$ level, while all variables are stable at I(1) level.

According to the results of the unit root test, the ARDL test can be applied if one of the variables under study is stable at I(0) level, the other is stable at I(1) level. Table 3 includes the results of the ARDL model established for the Eurasian countries and Turkey.

Table 3. ARDL long run results

\begin{tabular}{|c|c|c|c|c|}
\hline \multicolumn{3}{|c|}{ Eurasia } & \multicolumn{2}{|c|}{ Turkey } \\
\hline \multicolumn{3}{|c|}{$\begin{array}{c}\text { Dependent variable: Y } \\
\text { ARDL }(\mathbf{1}, \mathbf{1}, \mathbf{1}, \mathbf{1}, \mathbf{1})\end{array}$} & \multicolumn{2}{|c|}{$\begin{array}{c}\text { Dependent variable: Y } \\
\text { ARDL }(2,2,2,2,2)\end{array}$} \\
\hline \multicolumn{3}{|c|}{ Long-run coefficient } & \multicolumn{2}{|c|}{ Long-run coefficient } \\
\hline $\begin{array}{l}\text { Independent } \\
\text { variable }\end{array}$ & Coefficient & t-stat & Coefficient & t-stat \\
\hline$\chi$ & 0.53 & $2.65^{*}$ & -1.83 & $-111.15^{*}$ \\
\hline$\sigma$ & 0.15 & $3.64 *$ & 0.07 & $23.02 * *$ \\
\hline$\lambda$ & 0.06 & $2.03 * *$ & -0.04 & $-10.74 * * *$ \\
\hline$\delta$ & 1.34 & $8.50 *$ & 1.98 & $181.50 *$ \\
\hline
\end{tabular}

ARDL maximum lags were specified as automatic selection. *,** and *** mean significant, respectively, at $1 \%, 5 \%$ and $10 \%$. Y: $\mathrm{CO}_{2}, \chi$ : share of agricultural fields within total area, $\sigma:$ agricultural added value, $\lambda$ : GDP per capita, $\delta$ : population

According to the results of ARDL, all variables examined in the Eurasian countries were considered to be statistically important in the long run. The share of the agricultural fields within the total area, agricultural added value, $1 \%$ increase in GDP 
and population increase the $\mathrm{CO}_{2}$ level by $0.53 \%, 0.15 \%, 0.06 \%$ and $1.34 \%$ respectively. All variables studied in Turkey were considered to be statistically important. It was determined that the $\mathrm{CO}_{2}$ level decreases by $1.83 \%$ as the share of the agricultural fields within the total area increases by $1 \%$. In fact, this is related with the decreasing size of the agricultural fields in Turkey in recent years. As shown in Figure 3, the share of the agricultural fields within the total area decreased gradually after 2005. However, the forest areas in Turkey had an $11 \%$ increase during the study period despite the decreasing agricultural fields (Turkstat, 2018). The basic cause of this negative relation was dimensioned in this aspect. The positive relation between the agricultural added value and the $\mathrm{CO}_{2}$ level gives the idea that the wrong practices in the agricultural production activities create environmental pressure. However, the negative relation between the agricultural added value and the $\mathrm{CO}_{2}$ level can be explained with the environmentally improving effect of the agricultural sector (Khashman et al., 2016). That is, it can be said that the increase in agricultural fields may contribute to the decrease of the greenhouse effect and the destruction created thereby. A similar reverse directional relation is also seen in GDP. GDP is one of the most important parameters used to express the development levels of countries. The trend of GDP has significantly increased in recent years under the conditions of Turkey. According to the result, a 1\% increase in GDP causes a decrease of $0.04 \%$ in the $\mathrm{CO}_{2}$ level. It can be considered to be a result in line with the reverse relation appearing after the peak point of the Environmental Kuznets Curve (EKC) suggested by Simon Kuznets in 1958. As known, the peak point of EKC is stated as the level of awareness of the individuals (Kuznets, 1955). Under the conditions of Turkey, a $1 \%$ increase in population can be explained by a $1.98 \%$ increase in the $\mathrm{CO}_{2}$ level.

Short and long term causalities were determined with the Vector Error Correction Model for the variables affecting the $\mathrm{CO}_{2}$ level for the Eurasian countries and Turkey. Suitable lag length was determined before conducting the VECM causality analysis. Suitable lag length is given in Table 4.

Table 4. Lag length criteria for VAR model

\begin{tabular}{|c|c|c|c|c|c|c|c|}
\hline \multirow{4}{*}{ 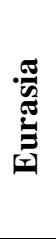 } & Lag & $\log L$ & LR & FPE & AIC & SC & HQ \\
\hline & 1 & 1745.681 & NA & $8.29 \mathrm{e}-14$ & -15.93224 & -15.54158 & -15.77441 \\
\hline & 2 & 2103.077 & 681.6993 & $3.82 \mathrm{e}-15^{*}$ & $-19.00997 *$ & $-18.22866^{*}$ & $-18.69432 *$ \\
\hline & 3 & 2124.706 & $40.25422 *$ & $3.94 \mathrm{e}-15$ & -18.97876 & -17.80679 & -18.50528 \\
\hline \multirow{4}{*}{ 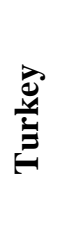 } & Lag & $\log L$ & $\mathbf{L R}$ & FPE & AIC & SC & HQ \\
\hline & 0 & 159.3997 & NA & $5.52 \mathrm{e}-13$ & -14.03633 & -13.78837 & -13.97792 \\
\hline & 1 & 315.6009 & 227.2018 & $3.91 \mathrm{e}-18$ & -25.96372 & -24.47593 & -25.61324 \\
\hline & 2 & 390.2824 & $74.68146 *$ & $6.52 \mathrm{e}-20^{*}$ & $-30.48022 *$ & $-27.75261 *$ & $-29.83767 *$ \\
\hline
\end{tabular}

According to the results of the lag length criteria, the lag length for the Panel VECM created for the Eurasia countries was 2, and the lag length for the Panel VECM created for Turkey was 2 as well. Table 5 includes the long and short term causality results obtained for the Eurasian countries and Turkey after determining suitable lag length. 
Table 5. VECM approach short run causality

\begin{tabular}{|c|c|c|c|c|c|c|}
\hline & \multicolumn{5}{|c|}{ Eurasia short-run causality } & \multirow{2}{*}{$\begin{array}{c}\text { Long run } \\
\text { ECT }\end{array}$} \\
\hline & $\mathbf{D}(\mathbf{Y})$ & $\mathbf{D}(\chi)$ & $\mathrm{D}(\sigma)$ & $\mathrm{D}(\boldsymbol{\delta})$ & $\mathbf{D}(\lambda)$ & \\
\hline $\mathrm{D}(\mathrm{Y})$ & - & 0.9744 & 3.0233 & 1.0030 & 0.0907 & $-0.0141^{*}$ \\
\hline $\mathrm{D}(\chi)$ & 1.2823 & - & 0.3571 & $5.9735^{* *}$ & 0.4358 & -0.0001 \\
\hline $\mathrm{D}(\sigma)$ & 1.0367 & 2.5298 & - & 2.7246 & $11.1840^{*}$ & $0.0240^{*}$ \\
\hline $\mathrm{D}(\delta)$ & 0.1642 & 0.1535 & 2.5210 & - & & -0.0001 \\
\hline \multirow[t]{2}{*}{$\mathrm{D}(\lambda)$} & 0.7102 & 0.2088 & 0.1517 & 0.5529 & - & $0.0270^{*}$ \\
\hline & \multicolumn{5}{|c|}{ Turkey short run causality } & $\begin{array}{c}\text { Long run } \\
\text { ECT }\end{array}$ \\
\hline $\mathrm{D}(\mathrm{Y})$ & - & 0.2016 & 0.1261 & $3.1334 * * *$ & 0.001 & $-1.325 * *$ \\
\hline $\mathrm{D}(\chi)$ & 2.004 & - & $6.346^{*}$ & 0.679 & $5.276^{* *}$ & -0.297 \\
\hline $\mathrm{D}(\sigma)$ & 1.330 & 0.043 & - & $8.353^{*}$ & 0.032 & $-7.972 *$ \\
\hline $\mathrm{D}(\delta)$ & $3.104 * * *$ & $3.540 * * *$ & $2.943 * * *$ & - & 1.875 & 0.009 \\
\hline $\mathrm{D}(\lambda)$ & 1.703 & 0.422 & 1.472 & $3.535 * * *$ & - & $-5.717 * * *$ \\
\hline
\end{tabular}

$*, * *$ and $* * *$ mean significant, respectively, at $1 \%, 5 \%$ and $10 \% . \mathrm{Y}: \mathrm{CO}_{2}, \chi:$ share of agricultural fields within total area, $\sigma$ : agricultural added value, $\lambda$ : GDP per capita, $\delta$ : population

According to the results of the VECM approach Short Run Causality relation, a causality relation was determined in the Eurasia countries in the short term from the agricultural fields to population and from the agricultural added value to GDP. In the long term, it is possible to see the effect of the agricultural added value and GDP. It can be said that the $0.014 \%$ difference between the observed value and realized value of the $\mathrm{CO}_{2}$ level would disappear within a period. In other words, the relevant imbalance can only disappear after 71 years if the conditions are maintained this way. When we look at the situation in Turkey, a causality relation was determined in the short term from the $\mathrm{CO}_{2}$ level to population, from the agricultural fields to GDP, from the agricultural added value to population, from population to $\mathrm{CO}_{2}$, agricultural fields and agricultural added value, and from GDP to population. Long term effect of agricultural added value and GDP are determined. It can be said that the $1.325 \%$ difference between the observed value and the realized value of the $\mathrm{CO}_{2}$ level will disappear after a period. In other words, the $\mathrm{CO}_{2}$ level will be balanced every 9 months if the conditions in Turkey are maintained this way.

\section{Discussion and conclusion}

There is an increasing trend in the global release of greenhouse gas. This increase is contributed by the countries of the world by various rates. The condition in the Eurasian region which is examined in the present study is different. Overall a decrease is observed in the region despite countries among the Eurasian countries showed increases and decreases between 1993 and 2016 years. This decrease is at the level of $13.91 \%$ (World Bank, 2017). In Turkey, there was an increase of $110 \%$ during the period of the study (Turkstat, 2018). The share of the agricultural fields within total area, agricultural added value, effect of GDP and population were analyzed by means of ARDL and VECM in order to determine this increase and decrease. 
Accordingly, all variables studied in the Eurasian region have an effect increasing the $\mathrm{CO}_{2}$ level in the long run. Population was determined to be the most effective variable. Similarly, population is considered to be the primary cause affecting the $\mathrm{CO}_{2}$ level under the conditions of Turkey. According to the results of the VECM analysis, in the Eurasian Region, the long-term deviations are eliminated in the short term, albeit with a very small proportion. As it can be seen from the results of the VECM analysis, it can be said that long term deviations in Turkey is not balanced in any way. When we consider the population increases in the period under study, a population increase of $2.16 \%$ took place in the whole Eurasian region, while this increase was $40.22 \%$ in Turkey in the same period (World Bank, 2017). Another effective variable determined after population was the share of agricultural fields within the total area. A linear relation was determined between the share of the agricultural fields and $\mathrm{CO}_{2}$ release in the Eurasian region while there was a negative directional relation in Turkey. However, the share of the agricultural fields within the total area of the Eurasian region was 55.09\% between 1993 and 2006 while this value was 51.53\% in Turkey. However, the cultivation status of the total agricultural fields, ratio of the forest lands and the product patterns in the agricultural fields are different in the Eurasian region and Turkey. Mostly the product group of grains are cultivated in the Eurasian region with intensive agriculture every year. However, the share of the agricultural fields within total area during the period of the study has gradually decreased in Turkey despite heavy agricultural activities. Soilless agriculture, environment friendly production systems and corresponding policy actions were taken as well. This is totally related to the intention of agriculture to reduce greenhouse gas release. While a one-way causality was determined between the agricultural fields and population in the Eurasian region in the short run, there was no such causality in Turkey. When we look at long term causality, long term deviation in the Eurasia Region does not appear to be reversible in the short run. With regards to the agricultural added value, effects increasing $\mathrm{CO}_{2}$ release were determined in both regions, and balancing long term deviations in the short run was considered to be statistically important. GDP is another variable with differences between regions. There is a positive directional and linear relation between GDP and environmental destruction in the underdeveloped countries while it is possible to see a negative directional relation in the developing or developed countries. This can be explained by the presence of the individuals in the country under the study and the policies implemented for that purpose. Turkey consists of a structure which is, even partly, more developed, has higher income level and possesses social awareness. This difference can be seen in the reports of the United Nations development plans.

In summary, the quality and sustainability of the world we live in and the life conditions in the world are dependent on humans. Human-induced deterioration is also expressed in scientific studies (Kadıoğlu, 2002; Türe, 2003). For example, every year, a result of human activities $\mathrm{CO}_{2}$ level increases by 3 billion tons (Bozoğlu et al., 2003; Karakaya and Özçağım, 2004). Environmental cost should definitely be taken into consideration while carrying out both agricultural activities and other income generating activities. All countries of the world should ensure conscientious individuals and informed development processes. Contributions should be made to raise awareness and improve education in underdeveloped countries and regions. States and policy makers should implement the laws on environmental issues and make them enforceable. All relevant ministries and organizations should be extremely sensitive and definitely take 
steps in their action plans to protect environmental plans. In conclusion, a destructed environment, polluted water and atmosphere affect all humans.

\section{REFERENCES}

[1] Altıntaş, H. (2013): Türkiye'de petrol fiyatları, ihracat ve reel döviz kuru ilişkisi: ARDL sınır testi yaklaşımı ve dinamik nedensellik analizi. - Uluslararası Yönetim İktisat ve İşletme Dergisi 9(19): 1-30.

[2] Angel, J. (2008): Potential Impacts of Climate Change on Water Availability. - Illinois State Water Survey, Institute of Natural Resource Sustainability, Champaign, IL.

[3] Anonymous https://en.wikipedia.org/wiki/List_of_Eurasian_countries_by_population.

[4] Bayraç, N., Doğan, E. (2016): Türkiye'de İklim Değişikliğinin Tarım Sektörü Üzerine Etkileri. - Eskişehir Osmangazi Üniversitesi İ̈BF Dergisi, Nisan 11(1): 23-48.

[5] Bozoğlu, B., Keskin, B., Çavdar, S. (2003): Küresel Isınma. - 6. Çevre Sorunları Öğrenci Yaklaşımları Sempozyumu Nisan 2003, Mersin.

[6] Carson, D. J. (1999): Climate modelling: achievements and prospects. - Quarterly Journal of Royal Meteorological Society 125: 1-28.

[7] Choi, I. (2001): Unit root tests for panel data. - J Int Money Financ 20: 249-272.

[8] Enders, W. (2008): Applied Econometric Time Series. - John Wiley \& Sons, Hoboken, NJ.

[9] Engle, R. F., Granger, C. W. (1987): Co-integration and error correction: representation, estimation, and testing. - Econometrica: Journal of the Econometric Society 251-276.

[10] Gafari, SH., Galalinasab, M., Ervani, H. (2014): Assessing the economic impact of climate change on agriculture. - National Conference on Climate Change and Sustainable Development of Agriculture and Natural Resources Engineering, Tehran.

[11] Granger, C. W. (1988): Some recent development in a concept of causality. - Journal of Econometrics 39(1-2): 199-211.

[12] Hadri, K. (2000): Testing for stationarity in heterogeneous panel data. - Econometric Journal 3: 148-161.

[13] Holly, R. (2015): The Complicated Relationship between Agriculture and Climate Change. - http://investigatemidwest.org/2015/07/09/thecomplicated-relationshipbetween-agriculture-and-climate-change/.

[14] Hosseini, S. S., Nazari, M. R., Araghinejad, S. (2013): Investigate of climate change effects on the agricultural sector, with emphasis on the implementation of the strategies in this section. - Iran Agricultural Economics and Development Research 1: 1-16.

[15] Im, K., Pesaran, M., Shin, Y. (2003): Testing for unit roots in heterogeneous panels. - J Econom 115: 53-74.

[16] IPCC (2014a): IPCC Fifth Assessment Report: Climate Change 2014 (AR5). - IPCC, Geneva.

[17] IPCC (2014b): Climate Change 2014: Synthesis Report. Contribution of Working Groups I, II and III to the Fifth Assessment Report of the. - IPCC, Geneva.

[18] Janjua, P. Z., Samad, G., Khan, N. (2014): Climate change and wheat production in Pakistan; autoregressive distributed lag approach, NJAS. - Wageningen Journal of Life Sciences 68: 13-19.

[19] Johansen, S. (1988): Statistical analysis of cointegration vectors. - Journal of Economic Dynamics and Control 12(1): 231-54.

[20] Johansen, S., Juselius, K. (1990): Maximum likelihood estimation and inference on cointegration with application to the demand for money. - Oxford Bulletin of Economics and Statistics 52: 169-210.

[21] Kadığlu, M. (2001): Bildiğimiz Havaların Sonu Küresel İklimDeğişimi ve Türkiye. Güncel Yayıncılık, İstanbul. 
[22] Kang, Y., Khan, S., Ma, X. (2009): Climate change impacts on crop yield, crop water productivity and food security. A review. - Prog. Nat. Sci. 19(12): 1665-1674.

[23] Kao, C., Chiang, M. (2000): On the estimation and inference of a cointegrated regression in panel data. - Adv Econom 15: 179-222.

[24] Karakaya, E., Özçağım, M. (2004): Sürdürülebilir kalkınma ve iklim değişikliği: Uygulanabilecek iktisadi araçların analizi. - Kırgızistan-Türkiye Manas Üniversitesi I. Maliye Konferansı 16 Nisan, Bişkek.

[25] Kaygusuz, K. (2009): Energy and environmental issues relating to greenhouse gas emissions for sustainable development in Turkey. - Renewable and Sustainable Energy Reviews 13: 253-270.

[26] Khashman, A., Khashman, Z., Mammadli, S. (2016): Arbitration of Turkish agricultural policy impact on $\mathrm{CO}_{2}$ emission levels using neural networks. - Procedia Computer Science 102: 583-587.

[27] Kuznets, S. (1955): Economic growth and income inequality. - The American Economic Review 45(1): 1-28.

[28] Levin, A., Lin, C., Chu, C. (2002): Unit root tests in panel data: asymptotic and finite sample properties. - J Econom. 108: 1-24.

[29] Maddala, G., Shaowen, W. (1999): Comparative study of unit root tests with panel data and a new simple test. - Oxf Bull Econ Stat 61: 631-652.

[30] Magadza, C. (2000): Climate change impacts and human settlements in Africa: prospects for adaptation. - Environ. Monit. Assess. 61: 193-205.

[31] MacKinnon, J. G. (1996): Numerical distribution functions for unit root and cointegration tests. - J. Applied Econ. 11: 601-618.

[32] Pesaran, H., Shin, Y. (1995): An Autoregressive Distributed Lag Modelling Approach to Cointegration Analysis. - In: Strom, S., Holly, A., Diamond, A. (eds.) Centennial Volume of Ranger Frisch. Cambridge University Press, Cambridge.

[33] Pesaran, H., Shin, Y., Smith, R. J. (2001): Bound testing approaches to the analysis of long run relationship. - Journal of Applied Econometrics 16(3): 289-326.

[34] Reynolds, L., Wenzlau, S. (2012): Climate-friendly agriculture and renewable energy: working hand-in-hand toward climate mitigation. - Renewable Energy World, 21 December 2012.

[35] Sakurai, Y., Song, K., Tachibana, S., Takahashi, S. (2014): Volitional enhancement of firing synchrony and oscillation by neuronal operant conditioning: interaction with neurorehabilitation and brain-machine interface. - Front. Syst. Neurosci. 8: 1-11.

[36] Özdemir, F., Küçükçongar, M., Arısoy, R.Z., Öztürk, E., Önder, M., Kan, M., Kınacı, İ., Y1lmaz, T., Yorgancilar, M., and Şahin, M., 2017. Agricultural Drought Perception and Its Socio-Economic Impacts in KOP Region Project Report (in Turkish), Ministry of Development, KOP Regional Development Agencies and The Ministry of Food Agriculture and Livestock, Konya.

[37] Tiwari, A. K. (2011): Primary energy consumption, $\mathrm{CO}_{2}$ emissions and economic growth: evidence from India. - SEE Journal 6(2): 95-113.

[38] Türe, E. (2003): Küresel Isınma ve Temiz Enerjiler. - III. Atmosfer Bilimleri Sempozyumu 19-21 Mart Haliç Üniversitesi, İstanbul.

[39] Turkstat (2018): www.tuik.gov.tr.

[40] World Bank (2016a): World Development Indicators: Agricultural Methane Emissions. http://data.worldbank.org/indicator/EN.ATM.METH.KT.CE.

[41] World Bank (2016b): World Development Indicators: Agricultural Nitrous Oxide Emissions. - http://data.worldbank.org/indicator/EN.ATM.NOXE.AG.ZS.

[42] World Bank (2017): http://databank.worldbank.org/data/reports.aspx?source=worlddevelopment-indicators. 